\section{James VI, Prince Henry, and $A$ True Reportarie of Baptism at Stirling 1594}

\section{RICK BOWERS}

Traditionnellement, le baptême d'un premier né royal — en particulier un fils - donne lieu à bien des célébrations et festivités à caractère politique. En 1594, Jacques VI d'Écosse a élevé le baptême de son fils à un degré surprenant d'art politique à travers le medium imprimé. Pourtant, malgré qu'il ait été publié simultanément à Londres et Édimbourg, A True Reportarie décrivant le baptême du prince Henri dans la nouvelle chapelle royale de Stirling Castle est resté largement ignoré par les critiques et les historiens; cela, sans doute en raison de l'anglocentrisme qui a marqué l'époque des Stuart à partir de 1603, lorsque Jacques est monté sur le trône anglais. La relation du baptême de Henri en 1594 documente, par ailleurs, par voie d'annonce et de performance, l'agenda politique radicalement optimiste de Jacques VI. A travers les thématiques de prouesse royale et de programme dynastique, A True Reportarie (1594) constitue une nouvelle forme d'annonce politique, le communiqué Protestant réformé, en rupture avec le passé catholique, qui met en équilibre le nationalisme écossais et l'union britannique, et exprime les complexités culturelles à venir du règne de Jacques.

$\mathrm{T}$

raditionally in Scotland, the baptism of a firstborn royal child - especially a son-occasioned much in the way of political festivity and celebration. In 1594, James VI of Scotland raised the baptism of his son to hitherto unknown levels of political art through the new medium of print. And yet, although published simultaneously in Edinburgh and London, the significance of $A$ True Reportarie of Prince Henry's baptism remains largely ignored by critics and historians due to a prevalent Anglocentric bias that dates Stuart culture from 1603, when James succeeded to the English throne. Henry himself did not survive past his late teens, but the baptismal report of 1594

Renaissance and Reformation / Renaissance et Réforme, XXIX, 4 (2005) /3 
documents - even as it mimetically performs - the radically hopeful agenda of James VI. And while the form of the piece as festive art would soon be superseded by the masques of Ben Jonson, those sumptuous and well-funded Jonsonian masques never featured a lion in the banquet hall, nor a fully rigged, fully armed, ocean-going vessel docking with a cargo of seafood. Both of these surprising dramatic effects, however, occur within A True Reportarie where they relate significantly to themes of royal prowess and dynastic intentions. In this essay, I will argue that $A$ True Reportarie (1594) represents a new form of political announcement, a reformed Protestant communiqué that breaks with a Catholic past, balances Scottish nationalism with British union, and asserts the cultural complexities of James's future power. ${ }^{1}$

A True Reportarie receives some attention within Michael Lynch's recent historical essay titled "The Reassertion of Princely Power in Scotland: The Reigns of Mary, Queen of Scots and King James VI," but the ceremony is still seen in terms of courtly extravagance and misdirected ambition on the part of James VI in the latter part of sixteenth-century Scottish court culture. ${ }^{2}$ Both criticisms apply in some measure, but I argue that the baptismal ceremonies and their published account both portray and promise much more. As printed publication especially, this festival of baptism reported to Europe that Henry would peacefully, and by family right, inherit both Scottish and English rule. The intended audience clearly reaches beyond the courtiers and diplomats assembled at Stirling Castle. As for domestic political messages and effects, contemporary Scottish nobility attended the event in a renovated attitude of peaceful conciliation almost without precedent at that time. International observers from the Continent also attended and endured the inconvenience of waiting for the arrival of a large English delegation. This group featured, as ambassador-extraordinary, the fifth Earl of Sussex, taking part personally as proxy for Queen Elizabeth of England who had agreed to be godmother to the infant prince. The Reportarie especially and dramatically stressed the kingly magnificence of James VI along with a new cultural sense of balance that separated his court from the tumultuous administration of his mother Mary Queen of Scots. Moreover, unlike Mary's renowned but unreported liturgical festivities for the baptism of James, James's Protestant celebration for his son would elicit — even as it asserted through print—English sympathies in terms of court, church, and culture.

Of course Mary had been magnificent in her own way at the baptism of James. A previous essay by Michael Lynch argues that the December 1566 baptismal festivities for the infant who would become James VI represented the high point of the personal rule of Mary Queen of Scots even as it celebrated the first truly Renaissance festival to occur in Great Britain. 
Lynch adduced treasurers' accounts, personal letters, Catholic continental influences, and diverse contemporary comment in describing the three-day celebration as Queen Mary's "triumph." He also, however, conceded a key point: "Its magnificence would be overtaken only by the baptismal celebrations, also held at Stirling, for James VI's first son, Henry, in 1594."3 Such an understated conclusion begs for fuller focused treatment on the document itself, especially as it relates to political power through the nascent power of print unleashed by James through authorized publication of the Reportarie of Henry's baptism.

In a recent article titled "God-fathering Prince Henry," Richard Hillman notes the connection between James VI's diplomatic manoeuvrings in anticipation of his English succession and the political significance of Henry in assuring that orderly succession. As Hillman slyly puts it, "Nothing, it would seem, succeeds like succession," 4 but he departs from the Reportarie to argue more generally in terms of James's relation to the English throne, to political themes in Shakespeare, and to Henri IV of France. Feminist critic Clare McManus considers both Henry's baptism and the ensuing entertainments as refracted through the romantic quest motif linked to the absent presence of Queen Anna. ${ }^{5}$ My approach focuses more directly on the Reportarie of baptism as a document in its own right with significant political inflections of performance signaled within themes of reformation, royalty, family, hope, and unity. The infant Prince Henry of Scotland plays an unprecedented paradoxical and central role, one that symbolizes ideals of political unification within a figure of power that elides national and cultural differences - especially between England and Scotland. If domestic - and therefore political — unity at this time was more apparent than real, due to James's personal jealousy and egoism as argued by David Bergeron, then the effect of unity conveyed by the document is even more significant considering the structural tensions of contemporary Stuart political culture. ${ }^{6}$

\section{Print, Power, and Performance}

The Reportarie of Prince Henry's baptism describes the performance of new political themes representing Stuart family values and therefore political values. These values combined with a new sense of internationalism - especially in relation to the throne of England - to represent James VI and his family in terms of future-oriented triumph and of reformed Renaissance magnificence. For the baptism, James built a new Chapel Royal within Stirling Castle over the site of a decaying medieval church. The Reportarie details James's expenses, various invitations, and complex preparations for the great event. Such 
descriptions of royal involvement necessarily emit and affirm signs of policy within a political class, but also - in this case - for a mass public readership. In Art and Power, Roy Strong describes the European context of such commemorative literature directly related to spectacle, including descriptions of architecture, allegorical devices, royal entries, colourful costumes, and lavish banquets - all reported in journalistic detail for a reading public to savour after the event. Indeed printed publication literalizes the significance of the event and its extended influence over a population. As Strong puts it,

By 1600 no major festival went unrecorded in print, the publications were on a lavish scale and illustration became the norm. The coincidence of this development with the emergence of absolutism and in the quest for messianic rulers around the year 1600 cannot be accidental. ${ }^{7}$

By 1594, in Scotland, King James's sense of divine absolutism already exceeded lavish commemoration to assert political philosophy, and his son's baptism provided the perfect platform on which to dramatize the politics of a promising future.

"Lavish," however does not describe the modest pamphlet form of the Reportarie. Set in black-letter type, the little booklet seems decidedly more popular than regal. It qualifies as a journalistic "report," but also contains the scripted quality of later masques and entertainments. In fact, its very designation "reportarie" is singular according to the $O E D$. As such it distinguishes itself even as it achieves political aims including historical record, statement of policy, and announcement of new direction. Moreover, published in English rather than Scots, the document was aimed at an English readership. Its modern editor, Henry W. Meikle blandly observes, "Political reasons may have dictated the choice."8 But political reasons doubtless governed the choice. King James understood the power of print and of language, specifically urging Henry a few years later to "use a plaine, short, but stately stile, both in your Proclamations \& Missives, especially to forraine Princes," adding remarkably, with regard to personal composition, "write in your own langage: for there is no thing left to be said in Greeke \& Latine already." 9 Prior to this advice from the Basilicon Doron, James had differentiated English from Scots in his "Essayes of a Prentise," as "lykest to our language," while conceding only, "we differ from thame in sindrie reulis of Poesie." 10 Historicist literary critic Sandra Bell relates both works to James's assertion of cultural policy, "by both joining the Scottish vernacular to and separating it from the English, James attempts to balance a movement to union with a movement to sovereignty - a balancing act which continued even into his reign in England."11 
This cultural balance, however, was struck early at the baptism of Prince Henry. Although penned by Scottish courtier William Fowler, the Reportarie serves the agenda and purposes of King James VI. Within a broadly courtcorporate sense of authorship (and one to which I will return), the Reportarie might well be considered as an early publication of James. It gets mentioned as such in Westcott's Introduction to New Poems by James I of England:

James had a hand also, with his friend William Fowler, in the games and shows at the christening of Prince Henry, August 23, 1594 [sic]. The entertainment at the banquet following the ceremony, according to Fowler, was intended by the King as an allegory representing the favor shown him by the gods during his voyage to Denmark and in the happy issue of his marriage. ${ }^{12}$

The allegory, however, looks forward as well as back, and deserves attention as a political document. Out of the secluded location of Stirling in 1594, central to Scottish political symbolism but rather remote to an English readership, comes a new form of political announcement and celebration that features the unifying possibilities of an infant British prince.

Within its pages the Reportarie refers somewhat self-reflexively to the actions described as "pastimes," "Interludes," Revels," and "rare shewes," including "Actors," a "mask," and "a silent Comedie." It documents a special occasion of court culture, involving primarily the ceremony of a royal baptism but also the ritual of royal pageantry. As always, such pageantry thrives within contexts of public precedence, martial competition, costly spectacle, and colourful display, reinforcing - as mysteries of power and magnificence - state, family, and international policy. As such the Reportarie exceeds the status of retrospective description or simple fantasy as implied in Westcott's dismissal of it as "pastimes of idle moments." 13 Rather, as a published document available on the street, the Reportarie both asserts itself and informs others in terms of political information. Inherently topical, the reception of this reported ritual entertainment involves the immediate royal family, assembled Scottish nobles, international ambassadors, a huge entourage of court functionaries and witnesses, as well as a reading public in both Scotland and England. The Reportarie both represents and extends official announcement, record, and indication of public policy. Make no mistake, it seems to say, this royal baptism represents more than a solemn Scottish occurrence, a courtly fete, or even political theatre; it is a statement of future British policy. ${ }^{14}$

The baptism of Prince Henry celebrated political ideals within a new economy of representation that asserted rebuilding (literally and figuratively), reformed Protestantism, reconsidered British polity, and mass publicity. This 
new political sense of "celebration" detaches itself from medieval liturgical forms - a daily celebration of mass - to become associated more widely with the circulation of published information, the building of a new Chapel Royal, and the elevation of policy linked to personal fame. Quite apart from Mary's Catholic masque at James's baptism, James provides a Protestant masque for his son. Roy Strong clarifies the ideological difference:

In countries that remained Catholic, ecclesiastical pomp in its new counter-reformation guise was to be complemented by what can only be called a liturgy of state which centred on the ruler. In the case of Protestant countries, there was not even a question of complement. It was one of total reversal. The liturgy of state ruthlessly replaced that of the medieval church. ${ }^{15}$

James celebrates Henry in Stirling, Edinburgh, and London and therefore publishes his fitness in terms of family expansion and political continuity. If ruthlessly performed in this case, one must remember that times and cultures had changed in Scotland by 1594: Mary Queen of Scots no longer exercised power in Scotland, and a totally reconstructed Chapel Royal at Stirlingwith the baptismal font as central architectural focus-fortified James's new position. Indeed the new Chapel Royal, solidified in stone and linked to Solomon's Temple, further enhanced James's "liturgy of state" by divine right. Lynch shrewdly observes the powerful symbolism: "James, as God's lieutenant on earth - it was in effect claimed - was now simultaneously King Solomon (the fount of wisdom), the biblical King David (whose Psalms the king had translated) and the Christian Emperor Constantine (responsible for the official adoption of a new religion)." ${ }^{16}$ Furthermore, this newly-reported, newly-baptized firstborn son of James - with Elizabeth I of England over 60 years old and childless - would doubtless (barring unforeseen calamity) one day rule as King of all Britain.

The Reportarie begins at a high level of mythological and political symbolism with the Scoto-Danish Arms featured prominently on the recto and verso of the title page. The English version more conventionally features only the commercial device of its London printer, Peter Short. But both editions open with a capsule biography of the new Prince of Scotland at the age of six months, ambassadorial announcements and invitations to his baptism, and relation of the massive expenditure - "an hundreth thousand pounds money of Scotland" (A2v) — for rebuilding of the Chapel Royal. Foreign ambassadors arrive from Denmark and the Low Countries with two important exceptions: no French ambassador ever arrives and the English ambassador arrives very late. In fact, the ceremony was delayed to the end of August chiefly due to "the long absence of an Ambassadour from England, which his Majestie 
greatly respected for many causes" (A3v). The Reportarie emphasizes that James hosted ambassadors at his own cost, "save onely the Ambassadour of England, whose whole expences were defrayed by his Soverane the Queene of England" (A3v). Assured of its own significance, the English entourage arrives with all the presumption of a wealthy family member. Scottish expenses face English expenses in a form of mutual détente. The costliest gifts for the new British prince will come from his godmother England, but neither English nor Scottish national administration will be publicly perceived as owing to the other.

And yet, through the infant prince, these two discrete national entities convey images of classical, cultural, religious, and even political unity toward each other. Indeed, Prince Henry's first mythological role as the infant Hercules was no doubt informed by the classical imagination and proud fatherly hopes of James. This initial image of Hercules and his travails, however, represents only the beginning of many performative images as understood by James in the well-known and oft-quoted advice to Prince Henry that opens the third book of Basilicon Doron: "A King is as one set on a stage, whose smallest actions and gestures, all the people gazinglie doe beholde."17 The baptism of Prince Henry was crucial as sacrament for a Christian prince, but even more significant as a performance of political hopes bounded only by a classical mental horizon of glory, ambition, and power.

James knew the format and proportions well whereby allegorical representations of elite authority combine within mythical history to dramatize the imagery and personality of legendary forebears. A few years earlier, he had demonstrated as much in his personal contributions to a masque for the marriage of the Earl of Huntly and Lady Henrietta Stuart. As described by literary historian Rhodes Dunlap in "King James's Own Masque," the show at Holyrood House involved an outdoor tilt, invocations to Cupid, Venus, Fortune, and many other Roman deities. James scripted three groups of male fauns, satyrs, and sylvans who arrive to take part in the sports along with a group of three wandering knights, totalling twelve competitors in all. This four-team structure mirrors the sports of the Reportarie. But although Dunlap draws the comparison, he dismisses James's involvement:

Such an arrangement would correspond with that for the tilting at Prince Henry's baptism in 1594, where there were three Turks, three Christian knights of Malta, and three Amazons, with preliminary plans calling also for three Moors. It might be added that James wrote no verses for that occasion and left the devising mainly to others, though he took active part as one of the Christian Knights of Malta. ${ }^{18}$ 
Fifty years ago, critics still saw authorship as a romantic one-to-one struggle with personal consciousness. The "works" of King James, however, always contained a largely corporate quality, much informed by others in authority at court and within the orbit of government. Doubtless, James was as enthusiastically involved in the arrangements for his son's baptism as he was directly - and for him unusually — involved in the sports, pageantry, and celebration of the event. But James's involvement in all forms of public expression includes his authority, reflecting what Curtis Perry refers to as "something closer to authorization than literal authorship."19 As absolute king, James saw himself in all matters of planning and policy, and perhaps most especially within royal festivities such as the fete at Stirling. Again, Perry describes in general terms James's relation to the Reportarie: "as his sponsorship of the King James Bible suggests, James may have had a broader sense of his authorial function than have subsequent critics." ${ }^{20}$ In this sense, all official expressions - especially one as significantly public and private as the Reportarie of Prince Henry's baptism - necessarily resonate with what James would consider to be his own commanded authority.

Perhaps not surprisingly, the Reportarie itself identifies James as originator: "The Kings Majestie, purposing further to decore by magnificence this action, committed the charge thereof to the Lord of Lendores, and M. William Fowler' (A4r). As functionaries, Lendores and Fowler are never mentioned again. Authorial significance involves relation of the king to the event, as well as relation of the kingly-authorized event to a wider public. In fact, as a published text the Reportarie can even report details of events that did not actually happen, including the cancelled ceremonies for the second day of what was originally planned to be a three-day festival. The craftsmen required for the event were "otherwise and necessarily busied" (B1v), but a parade of exotic, domestic, and mythological animals still gets reported by way of enthusiastic apology: "If it had bene brought to effect, this Countrie had not sene, nor practiced a more rarer: for what by the bravery and strange apparell of the persons themselves, and by the divers shapes of the Beastes, that should have beene born and broght ther in sight, had bene commendable and wonderfull" (B1v-B2r), including "Lyon, Elephant, Hart, Unicorne, and the Griphon together with the Camel, Hydre, Crocadile, and Dragon (carrying their riders)" (B2r). Hereby, the Reportarie integrates the event by actualizing it in print. James may not be in control of the exigencies of workmen or the lateness of English ambassadors, but through print such things can be reported, explained, and therefore defused to stress the importance of the baptism for a wider reading public. 
The Reportarie self-consciously refers to itself throughout as a royal presentation with a clear sense of its own histrionic (and therefore paradoxically real) display. Indeed, the Reportarie refers to the field events of the opening day in which James participated as a "mask" with "Nyne Actors, nyne Pages, and nyne Lackies, which comming from sundry parts and at divers times, together with the diversitie of their apparel, should bring some noveltie to the beholders" (A4r). The king's impresa might not have seemed so novel but receives a clear and significant description: "a Lyons heade with open eyes, which signifieth after a mistique \& Hierogliphique sence, Fortitude and Vigilancie" (A4v). A literalized lion will figure prominently later, but here a pageantry of martial prowess identifies the main actors who will participate at the baptism. Regarding its "noveltie," Lynch identifies these opening ceremonies as a tournament in the English style, having more in common with Elizabethan accession-day tilts than with Scottish kirk and court Protestantism: "the celebrations of 1594 as a whole were, in effect, a triumph of the Elizabethan succession, copying English chivalric festivals." 21 Doubtless, some in attendance cavilled at the innovation but publication of the event marks it for an audience outside of Scotland. Besides, written in English and directed toward an English audience, the Reportarie also reports a significant Scottish triumph: "the victorie fel to the Duke of Lennox" (B1v), followed by a statement of general satisfaction: "Thus the first dayes pastime was ended, with great contentment to the beholders, and commendation of the persons enterprysers" (B1v). Lennox, as youthful favourite, will play an even more significant role the following day at Henry's baptism. Indeed, by royal approval, Ludovick Stuart, second duke of Lennox and son of James's great favourite Esme, will be the last Stuart to touch the Prince before handing him to the English ambassador extra-ordinary, for administration of the sacred rites.

\section{Baptism}

Accentuating the tripartite organization of the day before (as well as, doubtless, the threefold personality of the Divine), three presiding ministers officiated at the ceremony. The Reportarie describes situation and layout in gorgeously Episcopal terms:

In the middest of the Chappell Royall within the partition, where the Kings Majestie, the Ambassadors, and Prince with his convoy were placed, there was a newe pulpit erected: The same was richely hung with cloth of gold: All the pavement within this partition, was Prince-like laide with fine tapestrie 
Under the Pulpit was another deske, wherein sate in the middest, M. David Cunninghame, Bishop of Abirdene, M. David Lindesay, Minister of Leyth, and John Duncanson, one of the ordinary ministers to the Kings Majestie: Before whome was set a table, covered with yealowe velvote $(\mathrm{B} 2 \mathrm{v})$.

This high church pageantry and finery might seem rather beyond the stern literalism expected of a Calvinist Scottish baptism in 1594. But James would later advise Henry to sound the middle way in his rejection of religious extremes, "as well as ye represse the vaine Puritane, so suffer not proude Papall Bishops." 22 The three clerics described above-bishop, minister, and private chaplain - represent the inclusively personal version of such policy. Besides, recent historians argue that James's Anglicization of the Church of Scotland reaches farther back than previously suggested into his Scottish rule. Indeed, although unmentioned in Alan R. MacDonald's work on James and Anglicanism, Prince Henry's baptism illustrates James's sense of English church culture, with a ceremonial style that rejects papal supremacy while conferring structures of authority onto the English court and crown. In this early instance of public display, James balances cultural prerogatives of union and sovereignty. ${ }^{23}$

These ideals of power and authority manifest themselves outside the chapel as well. From the old palace to the new chapel, the inner close of the castle was lined on either side by 100 armed harquebusiers of Edinburgh - a massive and costly display of security. The kinetic pageantry of the event works itself out in the clearest blocking patterns of national, international, familial, and political significance. The Reportarie recounts the handling of the prince in the closest detail, signifying the movement from his own chamber "wrought with brodered work, containing the story of Hercules" (B3r) through the castle to his baptism, naming, and investiture. Herein, the English ambassador plays a part of the utmost significance as proxy for Queen Elizabeth herself. The Prince's powerful infant body moves through the hands of his nurse, to the Countess of Mar, to the Duke of Lennox, to the ambassador extraordinary of England who carries the baby, under a large canopy — "a fair high Pale made four-square, of Crimson Velvote" (B3v) - from his chamber to the Chapel Royal. Under the canopy walked English ambassador ordinary Robert Bowes, Scottish court favourite Ludovick Stuart Duke of Lennox, and the English ambassador extra-ordinary Robert Radcliffe Earl of Sussex, personally carrying the infant Prince. Around the pale, walked the other ambassadors, followed by the ladies of the entourage. The Prince's own honours follow, borne individually by various nobles of Scotland and enumerated as follows: "a Lavar of water," "a fair Basen," "a Towell," and "a low Crowne ... set with Diamonds, Saphires, Rubies, and Emerauldes" (B3v- 
B4r). At the head of the parade, the "Lyon King of Armes and the Heraulds his brethren" (B3v) combine formally to trumpet these sumptuous visuals. Armed men, royal caregivers, Herculean associations, costly accoutrements, precious stones, and the utmost regal formality - the event displays novelties of power. Printed publication of the event reports even as it reinforces that power. ${ }^{24}$

The Prince gets handed back to his nurse through a precise reverse ordering: Sussex to Lennox, to Lady Mar, to "Mistres Nurse" (B4r), charged with caring for the infant during the formal exercises to follow. Every movement related to the prince suggests duty, intimacy, significance, and sacredness. Biblical texts related to such care are sung and expounded upon by the clerics in attendance. Politicized royal chaplain Patrick Galloway preached from the text of Genesis 21 with its recounting of the miracle birth of Isaac to Abraham and Sara in their old age. Isaac, as Old Testament hero, clearly relates to Hercules as classical hero and both relate to Henry as the new princely hero combining the realms of Scotland and England. The Bishop of Aberdeen expounded upon the sacrament of baptism "firste in the vulgare tongue, and next in the Latine, to the end, all men might generallie understand" (B4r), and this concern for mutual, international understanding would be reinforced through the singing of Psalm 21 with its insistence on the desire, power, and reward of God accorded to a faithful king. The baby, as literalization of this powerful reward gets handed back, again through precise order, to the English ambassador-extraordinary as the Reportarie focuses- "Then they proceeded to the action" (B4r) - and climactically reports the baptismal naming in printed capitals: "he was named by all their consents, FREDERIK HENRIE, HENRIE FREDERIK, and so baptised" (B4v).

The chiasmic parallelism of the repeated names is a formality, but it also signals a triumphalism multiply reinforced for the first time within the chapel, outside its environs, and on to the general public in Edinburgh and London through print. The Reportarie is again precise: "This being done, Lyon King of Armes, with a loud voice, reportes these names thryse over: \& then after him, the rest of his brethren Herauldes, with Trumpets sounding, confirmed the same" (B4v). Throughout this key exercise of repetition and reinforcement, the English ambassador-extraordinary cradles the infant prince in his arms as proxy for Elizabeth I of England. Typically this action is performed by the baby's godfather, but the place of the French ambassador as proxy for Henri IV, described as "a faire wyde Chaire, with the dew ornaments pertaining therto, over which was set the Armes of the King of France" (B2r), remains conspicuously, theatrically empty. In effect, Elizabeth is godmother and godfather both, conveying a symbol of powerful political androgyny and 
unity. To emphasize this significant ceremonial feat, the Reportarie describes how, after completing the act, "the English Ambassadour alone, withdrawing himself on the one side was mette and attended on by two Groomes, who humblie on their knees, the one presenting a large rich Basen, the other a suitable Lavar, repleat with sweet water, wherewith the Ambassador washed" $(\mathrm{B} 4 \mathrm{v})$. This action of purification singles out and emphasizes the special effort and involvement of English support, significance, and reciprocity. The moment fuses even as it broadcasts a sense of mutual beholding between the two realms of England and Scotland.

Whether in physical terms or in printed terms, this climactic moment insists on its own significance. Invested with the new authority of print, the Reportarie clearly signifies - in Edinburgh, London, and throughout both realms of Scotland and England - that this infant is directly in line for the English throne. And English involvement continues in close contact through to the end of the prince's long day. After further formalities, including knighthood and ducal investiture, "the Prince was carried by the Ambassador of England, to his owne Chalmer of presence: where the most rich and rare propynes wer there presented" (C1v). Back upon his bed of state, decorated with the labours of Hercules and cradled in the arms of his nurse, the prince would again return to being a highly privileged baby boy. Invested as prince, knight, and duke, however, he is now publicly marked for succession.

\section{Banquet}

That night, James's dinner celebrations in the huge hall adjoining the chapel elaborately and artfully construct effects of power, order, ceremony, and symbolic significance related always to the new prince and his family ties. The Reportarie is clear that the "invention" of these ceremonies is the King's own, with two highlighted effects - a lion hitched to a chariot of goddesses, and a fully rigged ship guided by sea gods - suggested, approved, and realized by James.

The first one required immediate modification: a real lion drawing a chariot had to be replaced by a moor "very richly attyred" with "great chaines of pure gold" (C3r). Suggestively, an exoticized slave replaces the "king" of beasts. This literalization of a chariot containing six goddesses drawn in by

an actual lion could only have been concocted in the romantic imagination of James. A court record dated August 1594 makes it clear that James wanted that lion on the premises: 
Item be his majesties speciall command and directioun for transporting of the lyoun fra Haliruid house to Striveling and thairfra bak agane. ${ }^{25}$

And the Reportarie explains why:

This Chariot which should have bene drawn in by a Lyon, (but because his presence might have brought some feare, to the neerest, or that the sight of the lights and torches might have commoved his tamenes) It was thoght meet, that the Moore should supply that roome $(\mathrm{C} 4 \mathrm{r})$.

Considerations of safety overruled the dramatic effect of a literalized lion rampant in the room. Even though the central courtyard of the palace at Stirling castle had long been known as the "Lion's Den" and, historically, lions may have been caged there, it seems more likely that figurative royal lions relaxed there in the persons of kingly nobility. ${ }^{26}$ James sought to literalize this key symbol of Scottish royal power.

The dramatic effect that James hoped physically to create involved the king of beasts drawing "six Gallant dames, who represented a silent Comedie" (C3r-C3v). The six goddesses themselves were all sumptuously attired in satins of silver and crimson, "with Fethers, pearles, and Jewels upon their loose haire, in Antica forma" (C3v). Ceres, Faecunditie, Faith, Concorde, Liberalitie, and Perseverance - all represent powerful female attributes related to peace, plenty and endurance in political and familial terms. Their various Latin mottos, all translated into English in the Reportarie, ensure the publication of their various messages, for example: Ceres: "the plenteous Fields shall afoord all things"; and Faecunditie: "this Cuntrie is blessed by the Childe of the goddes" (C4r). These allegorical female virtues relate generally to Stuart public image and specifically to the new personal image of Prince Henry, modifying critics such as Williamson who see Henry strictly in terms of masculine aura. And yet the lion is too terribly unpredictable to perform except by imagination, a danger likewise grasped coincidentally by Bottom in Shakespeare's A Midsummer Night's Dream: "to bring in (God shield us!) a lion among ladies is a most dreadful thing." ${ }^{27}$ However, published report of the lion circulated in print on the streets of Edinburgh and London and thereby accomplished fuller effect than any literal appearance could have done.

The other dramatic dinner entertainment involved the arrival and docking of a ship within the banqueting hall. This fully rigged eighteen-foot vessel of 36 guns, flagged 40 feet high with James's own colours, sailed on a sea 24 feet long, and "her motion was so artificially devised within her self, that none could perceive what brought her in" (C4r). Like a fantastic ship of state 
ably crewed by deities, the huge vessel carried Neptune, Thetis, and Triton, and featured three Sirens, swimming and singing to musical accompaniment. The ship's mainsail, decorated with the arms of Scotland and Denmark (as reproduced on the title page of the Waldegrave edition of the Reportarie), included a Latin device appropriate to the new Prince of Scotland, but also translated into English for a popular readership: "Beholde, (O Prince) what doth make these kingdoms severally blessed joyntly (O Prince of hope) thou holdes, and hast together" (D1r). This ship of state already joins and sustains Denmark and Scotland. Fully laden, the ship, as well as its celebrated "Prince of hope," carries a freighted future with a southern tack toward England. Again, however, publication of this effect achieves more significance than its sumptuous but limited presentation in the banquet hall.

In fact, the Reportarie elaborates on a moral hieroglyphic that might not be readily perceived by wine-imbibing nobles. This effect is especially James's "owne invention," and the Reportarie pauses self-reflexively to explain as follows: "But because this devise caried some morall meaning with it, it shal not be impertinent to this purpose, to discover what is meant and propyned thereby" (D1r). This "inside" report, articulated strictly for the benefit of the readership, relates the distress that James and Anna had to overcome a few years before to become a married couple. Such personal reporting of royalty is unprecedented, but the Reportarie clearly recounts the dangerous historical circumstances as well as the happy result:

The Kings Majestie, having undertaken in such a desperate time, to sayle to Norway, and like a newe Jason, to bring his Queene our gracious Lady to this Kingdome, being detained and stopped by the conspiracies of Witches, and such devillish Dragons, thought it very meet, to followe foorth this his owne invention, that as Neptunus (speaking poetically, and by such fictions, as the like Interludes and actions are accustomed to be decored withal) joyned the King to the Queene.

So after this Conjunction, hee brought their Majesties as happely hither: and now at this her blessed delivery, did bring such things as the Sea affoords, to decore this festival time withal" (D1v).

As in a romantic fiction or play with a happy ending, Neptune ensures the Stuart family success through triumphing over witchcraft conspiracy and joining the royal couple together. A healthy male heir ensures the clear sailing of family continuance, political assertion, and magnificent plenty as literalized in the baptism of Prince Henry and the immediate feast of seafood delivered at the table of the international dignitaries.

Music and fireworks further punctuate the event, including "Violls with voices in plaine counterpointe" to Latin hexameter verses. These formal 
verses reinforce the significance of the event in classical terms of praise and plenty. Life, wealth, influence, and success - all assert themselves as linked in sacred terms to James and to Anna, mentioned by name as powerful giver of life. The panegyric climax of the piece, however, links Scotland itself to a bright horizon of possibility with the birth of a sacred prince. A concluding verse shifts back to the Old Testament, as a chorus of gods sing Psalm 128 with all of its significant stress on happiness, fruitfulness, blessing and hope: "Yea, thou shalt see thy children's children, and peace upon Israel."28 With its cargo unloaded, the ship rode at anchor while all assembled dined and enjoyed a variety of music. Finally, weighing anchor to the music of trumpets and hoboys, the ship "discharged the rest of her ordinance, to the great admiration of the beholders" (D2r). The king, queen, and ambassadors then made their way to another hall, probably near the king's lodging in the palace, for a "Prince-like desart of Suger" (D2v), ending this long day of festivity at "about three of the clock in the morning" (D2v).

But the Reportarie does not end there. Instead it rhetorically, and self-reflexively, pulls focus away from immediate performance to narrate a number of "daies ensewing" (D2v) in Edinburgh that culminate in a banquet aboard a Danish ship "so great, that shee could not enter the Harborow" (D3r). Like the lavish ceremonies, late hours, costly fabrics, magnificent nobles, and variety of seafood hitherto described, everything touched upon in the Reportarie relates to overwhelming expense and achievement - and all for a reading public. Herein political elites, their alliances, meetings, and celebrations receive positive reporting in the form of an entertaining communiqué. The Reportarie thus serves the purposes of political information and celebration even as it explains the displays of firepower that accompany the ships of the foreign ambassadors. Echoing the ordinance of the show vessel at Stirling, these ships ratify the baptism of an infant prince through displays of real firepower. The "whole Artillerie" of the Danish warship is answered by Scottish vessels with "six score gret shot"(D3r). Finally, as the vessels hoist sail and depart, each receives a salute of firepower from the cannons of Edinburgh Castle. The "report" of the Reportarie echoes the "report" of cannon fire at Edinburgh, which echoes the "report" of fireworks at Stirling Castle. At all points, the Reportarie "triumphs" even as it reports triumphant accomplishment.

\section{Reception}

The appearance of the Reportarie within popular print, however, renders this early accomplishment of Stuart political hopes as radically contingent within 
history. Publication itself ensures contingent complexities of reception, interpretation, and negotiation - not just by ambassadors and nobles, but by assembled spectators and, by extension, a popular readership of black-letter pamphlets throughout both kingdoms of England and Scotland - even to the point of Shakespeare's lion gag in A Midsummer Night's Dream. Furthermore, the Reportarie suddenly reappeared in print in 1603 at the time of James's English succession. Completely reset in Roman type, the title updates Prince Henry as "now Prince of Wales" but the body of the document itself contains no changes whatsoever in wording. ${ }^{29}$ As a document of political theatre describing royal precedence, the Reportarie goes beyond baptism to serve purposes of further publicity. Yet it must be remembered as a point of historical contingency that while Henry succeeded magnificently in his role as infant prince, he never did succeed his father and become a king.

But in August 1594, James VI certainly did succeed as Protestant king and father with Henry Prince of Scots installed and affiliated with great promise along political, cultural, and religious lines. Publication, however, also ensured that interpretation of the event was now out of King James's immediate control, as witnessed by the surprising typographical error "Babtism" on the title page of the first London edition (STC 11214.7). James VI in 1594 , however, must have felt that his dynastic claims were proceeding with unchallengeable security even though Queen Anna would protest the nursing of Henry at Stirling, and the ill-fated Earl of Essex would be inspired the following year to mount something of a protest at Queen Elizabeth's annual Accession Day tilt. ${ }^{30}$

Meanwhile, word of a significant royal baptism in Scotland was news on the streets of Edinburgh and London. Shakespeare seems to have read about it. The ambitious Earl of Essex probably did as well. Studiously Protestant as well as surprisingly Episcopal, the Reportarie details a lavish show of Scottish celebration, with significant English involvement. Mediating national differences, Henry plays the paradoxical role of infant British prince with great political promise and cultural possibility. As a consequence of his status within performance, he bears marks of mythological power, royal ascendancy, and - through further print publication-public availability. The fact that he was carried physically, and with exceptional care, in the arms of the English royal proxy marks the infant prince further with international significance. Powerfully innocent, Henry "has it all." King James authorizes his dynastic significance in terms of future-oriented policy while also ensuring a key retrospective precedent whereby the prince will bear the name of his illustrious Tudor English forefathers: Henry. 
As political art, broadcasting James VI's vision, the Reportarie would not be exceeded until the development of Ben Jonson's masques in the next century. Had Prince Henry survived into adult authority this piece would begin all historical discussion of Jonson's masques as well as seventeenthcentury royalist imperative. And even though future pressure on Prince Henry would intensify through key roles in Jonsonian masques such as Oberon (1611) and the Barriers (1610), in 1594 the show celebrating his baptism was all his own. He would never again be as powerful as he was on the day of his baptism, 30 August 1594. But through the Reportarie of that baptism, King James alerted all Europe to the fact that Stuart political power held promise for all of Britain.

\section{University of Alberta}

\section{NOTES}

1. The full particulars of the primary text: A True Reportarie of the most triumphant, and royal accomplishment of the Baptisme of the most excellent, right high, and mightie Prince, Frederik Henry; by the grace of God, Prince of Scotland. Solemnized the 30 day of August 1594. (STC 11214.6; Edinburgh: Robert Waldegrave, 1594 and STC 11214.7; London: Peter Short, 1594). I quote throughout from the 1594 Waldegrave edition, hereafter cited in text as Reportarie, with pagination in parentheses. Whenever quoting from old-spelling texts, I silently regularize all $i / j$ and $u / v$ reversals as well as use of long $s$ and the capitalization of proper nouns. In the twentieth-century, A True Reportarie was reprinted by the Scottish Text Society. See Henry W. Meikle, ed. The Works of William Fowler, STS 3rd ser., 7, Vol. II (Edinburgh: Blackwood, 1936), pp. 169-95.

The only modern biographical treatments of Prince Henry are by Roy Strong, Henry, Prince of Wales and England's Lost Renaissance (London: Thames and Hudson, 1986); and J. W. Williamson, The Myth of the Conqueror: Prince Henry Stuart: A Study of 17th Century Personation (New York: AMS Press, 1978). For recent exceptions to anglocentric history, see The Reign of James VI, a collection of essays edited by Julian Goodare and Michael Lynch (East Linton: Tuckwell, 2000); see also Keith M. Brown, Noble Society in Scotland: Wealth, Family and Culture, from Reformation to Revolution (Edinburgh: Edinburgh University Press, 2000); and Royal Subjects: Essays on the Writings of James VI and I, ed. Daniel Fischlin and Mark Fortier (Detroit: Wayne State University Press, 2002).

2. See Michael Lynch, "The Reassertion of Princely Power in Scotland: The Reigns of Mary, Queen of Scots and King James VI," Princes and Princely Culture 1450-1650, Vol. 1, ed. Martin Gosman, Alasdair MacDonald, and Arjo Vanderjagt (Leiden: Brill, 2003), pp. 199-238.

3. Michael Lynch, "Queen Mary's Triumph: the Baptismal Celebrations at Stirling in December 1566," Scottish Historical Review 69 (April 1990), p. 21.

4. Richard Hillman, "God-fathering Prince Henry," The Struggle for the Succession in Late Elizabethan England, ed. Jean-Christophe Mayer (Montpellier: Universite Paul-Valery, 2004), p. 313. 
5. See Clare McManus, "Marriage and the Performance of the Romance Quest: Anne of Denmark and the Stirling Baptismal Celebrations for Prince Henry," A Palace in the Wild: Essays on Vernacular Culture and Humanism in Late-Medieval and Renaissance Scotland, ed. L. A. J. R. Houwen, A. A. MacDonald, and S. L. Mapstone (Leuven: Peeters, 2000), pp. 175-98.

6. Bergeron cites a couple instances of contemporary hearsay; see Royal Family, Royal Lovers: King James of England and Scotland (Columbia: University of Missouri Press, 1991), p. 55.

7. Roy Strong, Art and Power: Renaissance Festivals 1450-1650 (Woodbridge, Suffolk: Boydell Press, 1984), p. 22. On the power of print in early modern Europe, see Elizabeth L. Eisenstein, The Printing Press as an Agent of Change (Cambridge: Cambridge University Press, 1979).

8. Henry W. Meikle, ed., The Works of William Fowler, STS 3rd ser., 13, Vol. III (Edinburgh: Blackwood, 1939), p. xxvii.

9. James Craigie, ed., The Basilicon Doron of King James VI, STS 3rd ser., 16 (Edinburgh: Blackwood, 1944), I: pp. 184, 186. I quote here from the 1599 Waldegrave version which Craigie reproduces in italics.

10. James Craigie, ed. The Poems of James VI of Scotland (Edinburgh: Blackwood, 1955), vol. 1, p. 67.

11. Sandra Bell, "Kingcraft and Poetry: James VI's Cultural Policy," Reading Monarch's Writing, ed. Peter C. Herman (Tempe: Arizona Center for Medieval and Renaissance Studies, 2002), p. 164.

12. Allan F. Westcott, ed., New Poems by James I of England (New York: AMS Press, 1966), pp. lviii-lix.

13. Westcott, p. lix.

14. My argument about courtly display and its significance owes much theoretically to the work of Stephen Orgel, Roy Strong, and others. See especially Orgel, The Illusion of Power: Political Theater in the Renaissance (Berkeley: University of California Press, 1975), as well as more recent collections of essays, including The Stuart Court and Europe, ed. R. Malcolm Smuts (Cambridge: Cambridge University Press, 1996), and The Politics of the Stuart Court Masque, ed. David Bevington and Peter Holbrook (Cambridge: Cambridge University Press, 1998).

15. Strong, Art and Power, p. 19. The OED notes first instances of "celebrate" in a secular sense from the 1590s: "to make publicly known, proclaim, publish abroad."

16. Lynch, "The Reassertion of Princely Power in Scotland," p. 226. On the style and dimensions of the Chapel Royal in relation to Solomon's Temple, see Aonghus MacKechnie, "James VI's Architects and Their Architecture," in The Reign of King James VI, ed. Julian Goodare and Michael Lynch (East Linton: Tuckwell, 2000), pp. 163-65.

17. Basilicon Doron, p. 163.

18. Rhodes Dunlap, “King James’s Own Masque,” Philological Quarterly 41 (January 1962), pp. 252-53 (249-56).

19. Curtis Perry, "Royal Authorship and Problems of Manuscript Attribution in the Poems of King James VI and I," Notes and Queries 244 [ns 46].2 (June 1999), p. 245. Regarding problems of authorship, see also Jonathan Goldberg, James I and the Politics of 
Literature (Baltimore: Johns Hopkins University Press, 1983); and Arthur F. Marotti, Manuscript, Print, and the English Renaissance Lyric (Ithaca: Cornell University Press, 1995).

20. Perry, p. 246.

21. Lynch, "The Reassertion of Princely Power in Scotland," p. 226. Lynch has modified his position on this point. In a previous essay titled "Court Ceremony and Ritual during the Personal Reign of James VI," he reported: "If it aimed to be a surrogate Elizabethan triumph, dedicated to the English queen as Henry's godmother, the Stirling baptism failed." See The Reign of James VI, ed. Julian Goodare and Michael Lynch (East Linton: Tuckwell, 2000), p.89. While still attuned to power and its complicated representations, Lynch, in his more recent work, makes no such disparaging claim of failure with regard to the baptism at Stirling.

22. Basilicon Doron, p. 81.

23. In this connection, see Alan R. MacDonald, "James VI and I, The Church of Scotland, and British Ecclesiastical Convergence," The Historical Journal 48.4 (December 2005): pp. 885-903.

24. This formal ordering for the baptism included scrupulous pre-planning. See "The ordoure how the Prince salbe convoyit to the Kirk," Calendar of State Papers Relating to Scotland and Mary, Queen of Scots 1547-1603, Vol. 11, ed. Annie I. Cameron (Edinburgh: H.M General Register House, 1936), pp. 411-12. On the suggestive associations of Hercules within early modern Europe, see J. R. Mulryne's Introduction to Court Festivals of the European Renaissance: Art, Politics and Performance, ed. J. R. Mulryne and Elizabeth Goldring (Aldershot, UK: Ashgate, 2002). Within this volume, see also the essay by Margaret M. McGowan, "The Renaissance Triumph and its Classical Heritage," esp. pp. 26-47.

25. Quoted from the "MS. Accounts of the Lord High Treasurer of Scotland", reproduced in Anna J. Mill, Mediaeval Plays in Scotland (Edinburgh: Blackwood, 1927), p. 335. For a brief description of the baptismal festivities at Stirling, see pp. 50-52.

26. See Eric Stair-Kerr, Stirling Castle: Its Place in Scottish History (Glasgow: James Maclehose, 1913), pp. 141-42.

27. Act 3, scene 1, lines 29-30. The suggestive coincidence was first noted by Edmond Malone in the eighteenth century. Arden editor Harold F. Brooks adduces the Reportarie in his Introduction to the play:

It is highly probable that when he wrote the Dream Shakespeare knew of an episode which occurred at the Scottish court in 1594. If so, that yields a terminus a quo: the Dream could not be earlier than the baptismal feast of Prince Henry, 30 August 1594, and probably not than the account of it in A True Reportarie, registered with the Stationers on 24 October.... Bottom and his fellows, likewise planning a performance before their sovereign, anticipate the fear that bringing "a lion among ladies" may produce, and likewise modify their plan in order to avoid it. It seems harder to dismiss this parallel as coincidence, than with E. K. Chambers and Peter Alexander to accept the Scottish incident as having lodged in Shakespeare's mind.

See A Midsummer Night's Dream, ed. Harold F. Brooks, The Arden Shakespeare, (London: Methuen, 1979), pp. xxxiv-xxxv. 
28. Quoted anachronistically but appropriately from the King James version. On historical settings for this music, including some questionable generalities regarding the ceremony, see John Purser, Scotland's Music: A History of the Traditional and Classical Music of Scotland (Edinburgh and London: Mainstream, 1992), pp. 116-118.

29. A true report of the most tryumphant, and Royall accomplishment of the Baptisme of the most Excellent, right High, and mightie Prince Henry Fredericke, By the grace of God, Prince of Scotland, and now Prince of Wales (STC 11214.8; London: Thomas Creede, 1603).

30. Making no mention of the Reportarie but sensitive to James's claim, Paul E. J. Hammer argues Essex's desperate attention-seeking of the following year in "Upstaging the Queen: The Earl of Essex, Francis Bacon and the Accession Day celebrations of 1595." See The Politics of the Stuart Court Masque, ed. David Bevington and Peter Holbrook (Cambridge: Cambridge University Press, 1998), pp. 41-66. On the complex issue of succession in relation to James, see the articles by Susan Doran, Bernard Bourdin, and Glenn Burgess in Section II of The Struggle for the Succession in Late Elizabethan England, ed. Jean-Christophe Mayer. 